\title{
Relationship between sex hormones and RIG-I signaling in peripheral blood mononuclear cells of patients infected with hepatitis $C$ virus
}

\author{
FANG PING WANG, PING AN ZHANG and XIAO YAN YANG \\ Department of Clinical Laboratory, Renmin Hospital of Wuhan University, Wuhan, Hubei 430060, P.R. China
}

Received February 10, 2017; Accepted July 14, 2017

DOI: $10.3892 /$ etm.2017.4829

\begin{abstract}
It has previously been suggested that men and women demonstrate differing immune responses to hepatitis $\mathrm{C}$ virus (HCV) infection, resulting in the investigation of the role of sex hormones and if they influence the anti-HCV response. The present study aimed to examine if hormone levels were associated with interferon (IFN) signaling pathways in peripheral blood mononuclear cells of 131 patients infected with HCV and 113 healthy controls. HCV infection was diagnosed based on the presence of anti-HCV antibodies and HCV RNA in serum. Expression of testosterone and estrogen was measured at the protein level using a competitive chemiluminescence immunoassay, and at the mRNA level using reverse transcription-quantitative polymerase chain reaction. $\mathrm{HCV}$-infected males had increased levels of estrogen and a decreased ratio of testosterone to estrogen compared with healthy male controls (all $\mathrm{P}<0.001)$. HCV-infected patients demonstrated a significantly decreased expression of IFN and retinoic acid-induced gene protein I (RIG-I), RIG-I mRNA compared with controls. Pearson correlation analysis revealed that among males, levels of RIG-I correlated with levels of IFN- $\beta$ mRNA ( $r=0.460)$, testosterone $(r=-0.500)$, and the ratio of testosterone to estrogen $(\mathrm{r}=-0.477$; all $\mathrm{P}<0.001)$. However, levels of RIG-I did not correlate with levels of IFN- $\alpha$ mRNA ( $\mathrm{r}=0.158)$ or estrogen $(\mathrm{r}=0.173$; both $\mathrm{P}>0.05)$. These results suggested that testosterone or the ratio of testosterone to estrogen may inhibit RIG-I signaling and thereby influence immune responses to $\mathrm{HCV}$ infection.
\end{abstract}

\section{Introduction}

Hepatitis C virus (HCV), a single-strand RNA virus of the Flaviviridae family, infects approximately 170 million people

Correspondence to: Dr Ping An Zhang, Department of Clinical Laboratory, Renmin Hospital of Wuhan University, 9 ZhangZhiDong Street, Wuhan, Hubei 430060, P.R. China

E-mail: haoyundao1225@outlook.com

Key words: sex hormone, RIG-I signaling pathway, hepatitis C virus worldwide (1). HCV replication in infected individuals triggers an innate immune response that is often ineffective: As many as $80 \%$ of $\mathrm{HCV}$-infected patients cannot eliminate the virus and develop chronic hepatitis, cirrhosis, and even liver cancer (2). Innate immune responses to HCV infection differ between men and women (3-5), leading to the question of whether sex hormones may influence these responses.

Innate immune responses are induced when pattern recognition receptors (PRRs), which are expressed on immune cells, especially antigen-presenting cells, recognize viral genetic material (6). PRRs include Rig-like helicase receptors, NOD-nucleotide binding oligomerization domain-like receptors and Toll-like receptors. PRRs trigger signaling pathways that induce the production and release of cytokines such as the type I interferons IFN- $\alpha$ and IFN- $\beta$

The central PRR activated in response to RNA virus infection is retinoic acid-induced gene protein I (RIG-I), a 5'-triphosphorylated, uncapped RNA-binding DexD/H-box helicase (7). After binding to viral RNA, RIG-I induces a host response in which the amino-caspase activation and recruitment domains (CARDs) interact with the amino-terminal CARD of the IFN- $\beta$ promoter-stimulator 1 (IPS-1) (7).

The present study explored whether differences in sex hormone levels between men and women may lead to differences in RIG-I signaling in peripheral blood mononuclear cells (PBMCs) during HCV infection. If so, this may help explain why men and women differ in innate immune responses to such infection.

\section{Materials and methods}

Patients and controls. A total of 131 patients with chronic HCV infection (mean age, 53.72 years; range, 22-88) treated at Renmin Hospital of Wuhan University were enrolled in the study. HCV infection was diagnosed based on the presence in serum of anti-HCV antibodies and HCV-RNA, in accordance with guidelines from the Chinese Society of Hepatology and the Chinese Society of Infectious Disease (8). The viral strain in all patients was determined to be genotype 1b. As controls, 113 healthy aged-matched volunteers (mean age, 53.19 years; range, 17-78) were also enrolled in the study.

The study protocol was approved by the Renmin Hospital Ethics Committee [(2013) E-lun word (KY-035)], and all study participants gave written informed consent. 
Blood collection and analysis. Peripheral venous blood (3 $\mathrm{ml})$ was collected from all study participants using procoagulant tubes and analyzed for sex hormone levels using a chemiluminescence immunoassay autoanalyzer (ADVIA Centaur XP, Siemens). Peripheral venous blood $(2 \mathrm{ml})$ was also collected into anticoagulant (EDTA) tubes. All blood samples were processed within a few hour of collection. PBMCs were isolated by Ficoll density gradient centrifugation, and total RNA was extracted using TRIzol (Bao Biotechnology, Dalian, China). RNA showing an absorbance ratio (260/280 nm) of 1.8-2.1 was used in subsequent analysis.

This RNA template was mixed with $1 \mu \mathrm{l}$ of oligo-dT primers, immediately centrifuged at $1,006 \mathrm{x} \mathrm{g}$ for $30 \mathrm{sec}$ and then incubated at $65^{\circ} \mathrm{C}$ for $5 \mathrm{~min}$. This mixture was combined with $4 \mu \mathrm{l}$ of reaction buffer, $2 \mu \mathrm{l}$ of dNTP mix, $1 \mu \mathrm{l}$ of ribonuclease inhibitor, and $1 \mu \mathrm{l}$ of reverse transcriptase, and then incubated at $42^{\circ} \mathrm{C}$ for $60 \mathrm{~min}$ followed by $72^{\circ} \mathrm{C}$ for $10 \mathrm{~min}$. The resulting cDNA product was stored at $-20^{\circ} \mathrm{C}$ until use.

This cDNA was then analyzed by real-time reverse transcription-PCR in reactions $(20 \mu \mathrm{l})$ containing $2 \mu \mathrm{l}$ of cDNA, $0.5 \mu$ l of each primer (Table I), $10 \mu$ l of SYBR Premix Ex Taq II (Bao Biotechnology), $0.4 \mu \mathrm{l}$ of ROXII, and $6.6 \mu \mathrm{l}$ of $\mathrm{ddH}_{2} \mathrm{O}$. Primers (Shanghai Biological Technology) showed good specificity based on primer dissolution curves and the amplification of a single band with the expected length. Reactions were performed on a thermal cycler (Thermo Fisher Scientific) under the following conditions: $94^{\circ} \mathrm{C}$ for $30 \mathrm{sec} ; 94^{\circ} \mathrm{C}$ for $20 \mathrm{sec}$; 50 cycles at $95^{\circ} \mathrm{C}$ for $15 \mathrm{sec}, 60^{\circ} \mathrm{C}$ for $20 \mathrm{sec}$ and $72^{\circ} \mathrm{C}$ for $35 \mathrm{sec}$. Reaction results were analyzed on a quantitative fluorescence analyzer (ABI VII7; Applied Biosystems). Amplification was considered efficient because the efficiency of all target gene reactions was $98-102 \%$, and the difference in efficiency between target genes (RIG-I, IFN- $\alpha$, IFN- $\beta$ ) and the internal reference gene (GAPDH) was $<5 \%$. This efficiency was assessed using five concentrations of 10 -fold serial dilutions. Gene expression was expressed in relative units $\left(\mathrm{RQ}=2^{-\Delta \mathrm{CT}}\right)$.

HCV RNA was quantified using an automatic nucleic acid extraction device and supporting reagents (Qiagen QIAcube), together with a LightCycler1.2 quantitative fluorescence PCR instrument (Roche). Amplicons were sequenced using an ABI 3130 (Applied Biosystems). HCV RNA load was determined using a Qiagen care HCV RT-PCR Assay V2 kit, which has a minimum detection limit of $5 \times 10^{2} \mathrm{IU} / \mathrm{ml}$.

Statistical analysis. All statistical analyses were performed using SPSS 19.0 (IBM, Chicago, IL, USA). Results showing a normal distribution were reported as mean \pm standard error (SD), while results showing a skewed distribution were expressed as median and interquartile range (IQR). Inter-group differences in continuous variables were assessed for significance using independent $\mathrm{t}$ testing, while differences in categorical variables were assessed using $\chi^{2}$ testing. Correlations between continuous variables were explored using Spearman correlation analysis. All p-values were two-sided, and the threshold of significance was defined as $\mathrm{P}<0.05$.

\section{Results}

Characteristics of the study population. Patients chronically infected with HCV and healthy controls differed significantly in liver function (Table II): The functional indices ALT, AST, ALP, GLB, DBIL, and hs-CRP were significantly higher in patients, while PA, TP, ALB, LDL, and PT-act were significantly lower (all $\mathrm{P}<0.01)$.

Serum levels of sex hormones in patients. Female patients with $\mathrm{HCV}$ showed similar levels of estrogen $\left(\mathrm{E}_{2}\right)$ and testosterone (T) as healthy female controls, as well as similar $\mathrm{T} / \mathrm{E}_{2}$ ratios (all $\mathrm{P}>0.05)$. Male patients with HCV showed significantly higher E2 levels than healthy males $(\mathrm{P}<0.001)$ and significantly lower $\mathrm{T} / \mathrm{E}_{2}$ ratio $(\mathrm{P}=0.041$; Fig. 1$)$.

Expression of mRNAs encoding IFN- $\alpha, I F N-\beta$ and RIG-I in PBMCs. Levels of mRNAs encoding IFN- $\alpha$, IFN- $\beta$, or RIG-I were significantly lower in patients than in controls $(\mathrm{P}<0.001$; Fig. 2).

Correlation of RIG-I mRNA levels with levels of sex hormones and IFN mRNA in males infected with HCV. RIG-I mRNA levels correlated negatively with levels of testosterone and $\mathrm{T} / \mathrm{E}_{2}$ (both $\mathrm{P}<0.001$ ) and positively with levels of IFN- $\beta$ mRNA $(\mathrm{P}<0.001$; Fig. 3 and Table III).

\section{Discussion}

Approximately 170 million around the world are infected with HCV (1), more than half of whom live in China as well as a few other Asian countries (9). In China, the primary cause of $\mathrm{HCV}$ infection is transfusion with contaminated blood (10). Men and women show important differences in the pathogenesis of liver diseases related to $\mathrm{HCV}$ infection. Following $\mathrm{HCV}$ infection, men are at higher risk than women of progressing to chronic hepatitis, cirrhosis or hepatic carcinoma (11). Women may be more able to clear HCV virus than men of the same age, and this difference disappears after menopause $(12,13)$. These observations suggest that sex hormones may influence outcomes of HCV infection.

Consistent with this idea, HCV-related liver fibrosis progresses faster in postmenopausal women than in premenopausal women, and estrogen replacement therapy can significantly delay this progression in postmenopausal women (14). Co-administering the estrogen analog Raloxifene with IFN and ribavirin leads to higher sustained virological response in women $(61.3 \%)$ than using IFN and ribavirin (34.4\%) (15). In HCV-infected patients, progesterone inhibits IFN signaling in PBMCs as well as TLR7 and MxA gene expression (16). These studies led us to ask whether sex hormones may also influence RIG-I signaling in PBMCs during $\mathrm{HCV}$ infection. If so, this may help explain the observed gender differences in $\mathrm{HCV}$-related pathogenesis and disease outcomes.

Our results suggest that levels of mRNAs encoding IFN- $\alpha$, IFN- $\beta$, and RIG-I are significantly lower in patients infected with $\mathrm{HCV}$ than in healthy controls (all $\mathrm{P}<0.001$ ). This association between reduced levels of RIG-I expression and HCV infection is consistent with the ability of RIG-I to bind to viral double-stranded RNA within cells and induce an IFN-based antiviral immune response $(17,18)$.

Among women in our study, levels of estrogen and testosterone as well as the $T / E_{2}$ ratio were similar between patients 
Table I. Primers used for reverse transcription-quantitative polymerase chain reaction.

\begin{tabular}{llll}
\hline Target gene & Upstream primer (5'-3') & Downstream primer (5'-3') & Product length (bp) \\
\hline RIG-I (NM_014314.3) & CCAGGGATCCCAGCAATGAG & TGTTTTGCGACGTCCAGTCA & 200 \\
IFN- $\alpha$ (NM_002176.2) & TGATCTCCCTGAGACCCACA & AGCAGGGGTGAGAGTCTTTGA & 591 \\
IFN- $\beta$ (NM_002176.2) & AGTAGGCGACACTGTTCGTG & TGCTCATGAGTTTTCCCCTGG & 446 \\
GAPDH (NM_002046.5) & AACGGATTTGGTCGTATTGG & AGATGATGACCCTTTTGGCT & 340
\end{tabular}

RIG-I, retinoic acid-induced gene protein I; IFN, interferon.

Table II. Clinical characteristics of healthy controls and patients infected with HCV.

\begin{tabular}{|c|c|c|c|}
\hline Characteristic & Controls $(\mathrm{n}=113)$ & Patients $(n=131)$ & P-value \\
\hline Age, years & $53.19(12.69)$ & $53.72(15.35)$ & 0.774 \\
\hline Male/female & $61 / 52$ & $62 / 69$ & 0.266 \\
\hline ALT, U/1 & $17.04(12.00-20.0)$ & $53.67(17.30-59.40)$ & 0.000 \\
\hline AST, U/1 & $19.77(17.00-23.00)$ & $53.94(22.00-52.00)$ & 0.000 \\
\hline ALP, U/1 & $69.57(55.50-79.00)$ & $87.31(57.25-97.00)$ & 0.001 \\
\hline GGT, U/1 & $18.73(12.00-24.50)$ & $43.60(15.75-55.15)$ & 0.000 \\
\hline $\mathrm{PA}, \mathrm{mg} / \mathrm{l}$ & $300.20 \pm 43.49$ & $175.66 \pm 85.18$ & 0.000 \\
\hline $\mathrm{TP}, \mathrm{g} / \mathrm{l}$ & $72.06 \pm 4.50$ & $66.87 \pm 12.32$ & 0.000 \\
\hline ALB, $g / 1$ & $43.05 \pm 2.85$ & $37.31 \pm 8.34$ & 0.000 \\
\hline GLB, g/l & $24.91 \pm 9.89$ & $29.08 \pm 7.20$ & 0.000 \\
\hline TBIL, umol/1 & $11.94(8.40-15.20)$ & $17.56(8.82-18.33)$ & 0.004 \\
\hline DBIL, umol/1 & $3.56(2.55-4.40)$ & $8.82(3.05-7.15)$ & 0.001 \\
\hline BUN, mmol/1 & $4.92(4.4 .-5.60)$ & $11.17(3.93-6.90)$ & 0.089 \\
\hline LDH, U/1 & $188.57 \pm 32.18$ & $187.74 \pm 74.79$ & 0.914 \\
\hline $\mathrm{TC}, \mathrm{mmol} / \mathrm{l}$ & $4.22(3.96-4.57)$ & $43.06(3.27-4.57)$ & 0.126 \\
\hline $\mathrm{TG}, \mathrm{mmol} / \mathrm{l}$ & $1.45(0.86-1.69)$ & $1.32(0.72-1.42)$ & 0.350 \\
\hline HDL-CH, mmol/1 & $1.24 \pm 0.30$ & $1.12 \pm 0.46$ & 0.025 \\
\hline LDL-CH, mmol/1 & $2.39 \pm 0.50$ & $2.03 \pm 0.80$ & 0.000 \\
\hline $\mathrm{CK}, \mathrm{U} / 1$ & $94.31(63.00-112.00)$ & $102.89(40.25-91.50)$ & 0.025 \\
\hline hs-CRP, mg/l & $1.20(0.10-0.96)$ & $20.69(0.15-8.47)$ & 0.000 \\
\hline $\mathrm{PT}$, sec & $10.98(10.50-11.30)$ & $13.13(10.90-12.20)$ & 0.047 \\
\hline PT-act, \% & $105.09(95.65-113.90)$ & 89.17 (77.90-104.60) & 0.000 \\
\hline PT-INR & $0.95(0.90-0.98)$ & $1.35(0.94-1.05)$ & 0.195 \\
\hline APTT, sec & $28.20(26.20-30.05)$ & $30.41(26.00-32.30)$ & 0.025 \\
\hline TT, sec & $18.07(17.60-18.50)$ & $19.05(17.40-19.90)$ & 0.017 \\
\hline FIB, g/l & $2.69 \pm 0.49$ & $2.40 \pm 0.85$ & 0.004 \\
\hline D-dimer, mg/l & $0.24(0.17-0.31)$ & $2.21(0.15-1.01)$ & 0.072 \\
\hline
\end{tabular}

Values shown are mean \pm SD or median (IQR). ALT, alanine aminotransferase; AST, aspartate transaminase; ALP, alkaline phosphatase; GGT, $\gamma$-glutamyl transpeptadase; PA, prealbumin; TP, total protein; ALB, albumin; GLB, globulin; TBIL, total bilirubin; DBIL, direct bilirubin; BUN, blood urea nitrogen; LDH, lactate dehydrogenase; TC, total cholesterol; TG, triglyceride; HDL-CH, high density lipoprotein cholesterol; LDL-CH, low density lipoprotein cholesterol; CK, creatine kinase; hs-CRP, hypersensitive C-reactive protein; PT, prothrombin time; PT-act, prothrombin time-act; PT-INR, prothrombin time international normalized ratio; APTT, activated partial thromboplastin time; TT, thrombin time; FIB, fibrinogen.

and healthy controls. Among men, in contrast, levels of estrogen were higher $(\mathrm{P}<0.001)$ and the $\mathrm{T} / \mathrm{E}_{2}$ ratio was lower $(\mathrm{P}=0.041)$ in patients than in controls. Our results contrast with the proposed ability of estrogen to protect against HCV-related liver pathogenesis, based on its ability to inhibit progression of HCV-related fibrosis (19).

We found that RIG-I mRNA levels correlated negatively with testosterone levels and $\mathrm{T} / \mathrm{E}_{2}$ ratios (both $\mathrm{P}<0.001$ ) and 

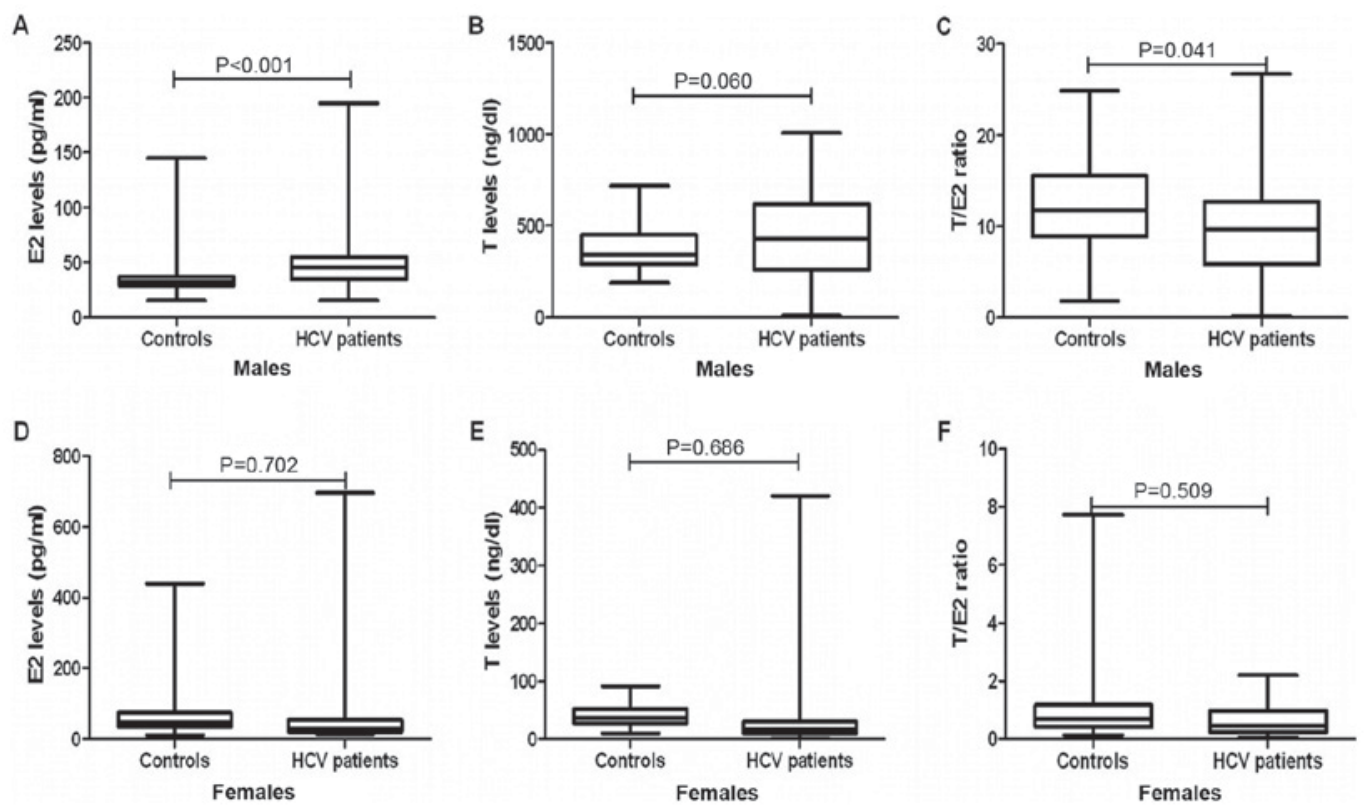

Figure 1. Comparison of sex hormone levels in healthy controls and patients infected with HCV, stratified by sex. Levels are shown as medians and interquartile ranges because data were not distributed normally. (A-C) Comparisons between male patients and male controls. (D-F) Comparisons between female patients and female controls. T, testosterone; $\mathrm{E}_{2}$, estrogen; $\mathrm{T} / \mathrm{E}_{2}$, ratio of testosterone to estrogen.
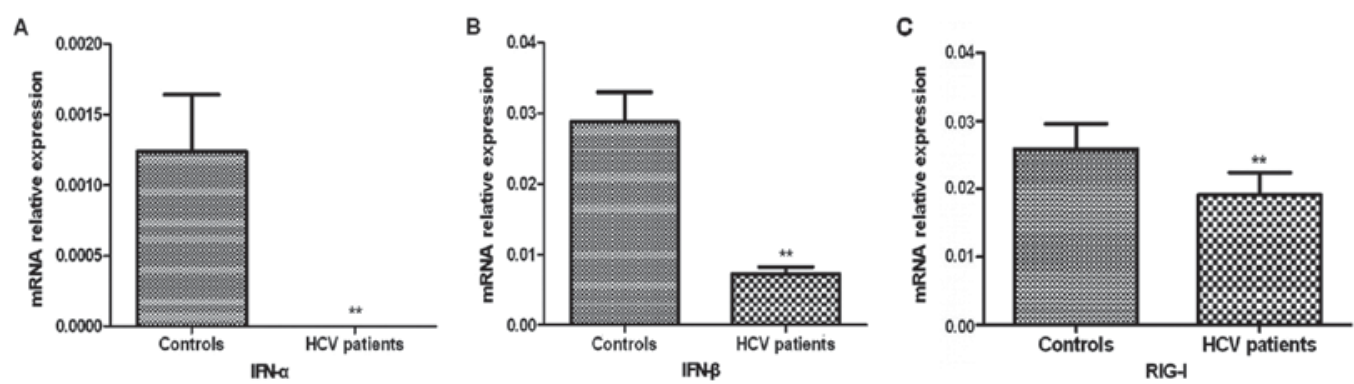

Figure 2. Expression of (A) IFN- $\alpha$, (B) IFN- $\beta$, and (C) RIG-I mRNAs in PBMCs from healthy controls and patients infected with HCV. ${ }^{* * *} \mathrm{P}<0.001 \mathrm{vs}$. control.

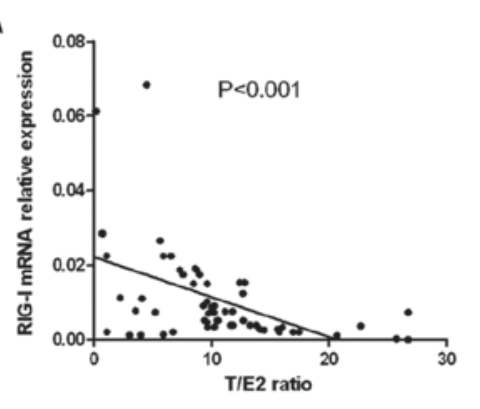

D

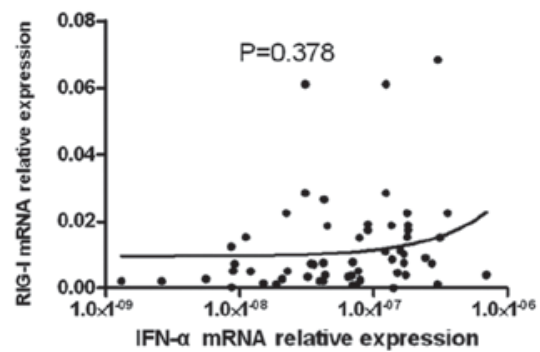

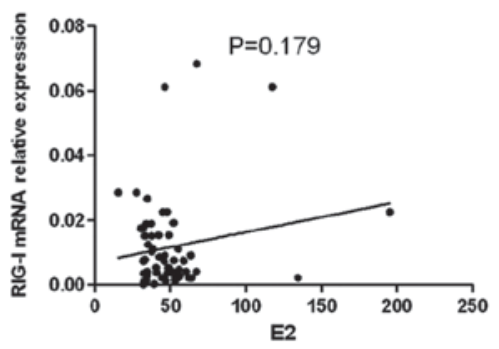

E

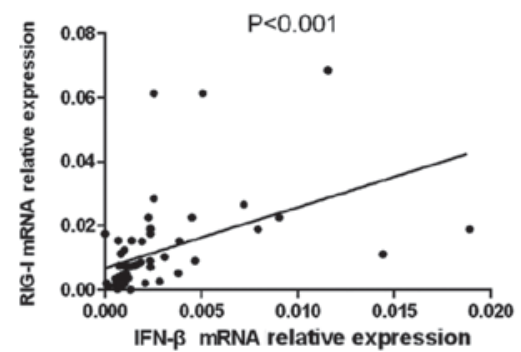

Figure 3. Correlation of RIG-I mRNA levels with levels of (A) ratio of testosterone to estrogen, (B) estrogen, (C) testosterone, (D) IFN- $\alpha$ mRNA or (E) IFN- $\beta$ mRNA in males infected with $\mathrm{HCV}$. 
Table III. Correlation of RIG-I mRNA levels with levels of sex hormones and IFN mRNA in males infected with HCV.

\begin{tabular}{lccccc}
\hline RIG-I & T & E2 & T/E2 & IFN- $\alpha$ & IFN- $\beta$ \\
\hline $\begin{array}{l}\text { Spearman } \\
\text { correlation } \\
\text { coefficient }\end{array}$ & -0.500 & 0.173 & -0.477 & 0.158 & 0.460 \\
\begin{tabular}{l} 
P-value \\
\hline
\end{tabular} & $<0.001$ & 0.179 & $<0.001$ & 0.221 & $<0.001$ \\
\hline
\end{tabular}

RIG-I, retinoic acid-induced gene protein I; IFN, interferon.

positively with IFN- $\beta$ mRNA levels $(\mathrm{P}<0.001)$. These results are consistent with studies in which men with elevated serum testosterone levels exhibited the lowest levels of antibody and inflammatory cytokines following viral infection $(20,21)$. Among men infected with $\mathrm{HCV}$, each $1 \mathrm{ng} / \mathrm{ml}$ increase in total serum testosterone has been associated with a $27 \%$ increase in risk of advanced fibrosis and $16 \%$ increase in risk of advanced inflammatory activity (22). One possible explanation for these 'proviral' effects of testosterone is that it alters lipoprotein production in a way that promotes HCV replication (23). Another possibility, for which the present study provides evidence, is that testosterone inhibits immune responses to $\mathrm{HCV}$ infection.

Our results add to an already sizeable literature demonstrating gender-based differences in innate and adaptive immune responses (24-29); these differences influence the pathogenesis and outcomes of infectious and autoimmune diseases. Our study also provides one of the few analyses of testosterone and $\mathrm{HCV}$ infection. Our results suggest that, following $\mathrm{HCV}$ infection, estrogen promotes immune hyperresponse, while testosterone inhibits immune responses. This implies that optimal immune response requires a dynamic balance between the two hormones. Future work should investigate this possibility by manipulating sex hormone levels and examining the resulting changes in RIG-I signaling in PBMCs.

\section{References}

1. Lauer GM and Walker BD: Hepatitis C virus infection. N Engl J Med 345: 41-52, 2001.

2. Lavanchy D: The global burden of hepatitis C. Liver Int 29 (Suppl 1): S74-S81, 2009.

3. Hannah MF, Bajic VB and Klein SL: Sex differences in the recognition of and innate antiviral responses to Seoul virus in Norway rats. Brain Behav Immun 22: 503-516, 2008.

4. Klingström J, Lindgren T and Ahlm C: Sex-dependent differences in plasma cytokine responses to hantavirus infection. Clin Vaccine Immunol 15: 885-887, 2008.

5. Bakr I, Rekacewicz C, El Hosseiny M, Ismail S, El Daly M, El-Kafrawy S, Esmat G, Hamid MA, Mohamed MK and Fontanet A: Higher clearance of hepatitis C virus infection in females compared with males. Gut 55: 1183-1187, 2006.

6. Gilliet M, Cao W and Liu YJ: Plasmacytoid dendritic cells: Sensing nucleic acids in viral infection and autoimmune diseases. Nat Rev Immunol 8: 594-606, 2008.

7. Yoneyama M and Fujita T: Structural mechanism of RNA recognition by the RIG-I-like receptors. Immunity 29: 178-181, 2008.
8. Chinese Society of Hepatology, Chinese Society of Infectious Diseases: Guidelines for prevention and treatment of hepatitis C virus. J Cin Hepatol 12: 775-780, 2004.

9. Gower E, Estes C, Blach S, Razavi-Shearer K and Razavi H: Global epidemiology and genotype distribution of the hepatitis $C$ virus infection. J Hepatol 61 (1 Suppl): S45-S57, 2014.

10. Pan YF, Zheng Y, Qin T, Feng L, Zhang Q, Ping XG, Pan YT, Wang XP, Bai L and Li HH: Disease progression in Chinese patients with hepatitis $C$ virus RNA-positive infection via blood transfusion. Exp Ther Med 12: 3476-3484, 2016.

11. Corsi DJ, Karges W, Thavorn K, Crawley AM and Cooper CL: Influence of female sex on hepatitis $\mathrm{C}$ virus infection progression and treatment outcomes. Eur J Gastroenterol Hepatol 28: 405-411, 2016.

12. Baden R, Rockstroh JK and Buti M: Natural history and management of hepatitis C: Does sex play a role? J Infect Dis 209 (Suppl 3): S81-S85, 2014.

13. Mekky RY and Abdelaziz AI: Sex hormones and HCV: An unresolved mystery. Expert Rev Gastroenterol Hepatol 7: 69-75, 2013.

14. Bernabucci V and Villa E: The role played by gender in viral hepatitis. Scand J Clin Lab Invest Suppl 244: 90-94, 2014.

15. Furusyo N, Ogawa E, Sudoh M, Murata M, Ihara T, Hayashi T, Ikezaki H, Hiramine S, Mukae H, Toyoda K, et al: Raloxifene hydrochloride is an adjuvant antiviral treatment of postmenopausal women with chronic hepatitis C: A randomized trial. J Hepatol 57: 1186-1192, 2012.

16. Tayel SS, Helmy AA, Ahmed R, Esmat G, Hamdi N and Abdelaziz AI: Progesterone suppresses interferon signaling by repressing TLR-7 and MxA expression in peripheral blood mononuclear cells of patients infected with hepatitis $C$ virus. Arch Virol 158: 1755-1764, 2013

17. Seth RB, Sun L and Chen ZJ: Antiviral innate immunity pathways. Cell Res 16: 141-147, 2006.

18. Shen Y, Qian Y, Shen L, Wu Z, Xu C and Tong X: Cloning and expression of retinoic acid-induced gene-I and its effect on hepatitis C virus replication. Lab Med 45: 103-110, 2014.

19. Di Martino V, Lebray P, Myers RP, Pannier E, Paradis V, Charlotte F, Moussalli J, Thabut D, Buffet C and Poynard T: Progression of liver fibrosis in women infected with hepatitis C: Long-term benefit of estrogen exposure. Hepatology 40: 1426-1433, 2004.

20. Furman D, Hejblum BP, Simon N, Jojic V, Dekker CL, Thiébaut R, Tibshirani RJ and Davis MM: Systems analysis of sex differences reveals an immunosuppressive role for testosterone in the response to influenza vaccination. Proc Natl Acad Sci USA 111: 869-874, 2014.

21. Posma E, Moes H, Heineman MJ and Faas MM: The effect of testosterone on cytokine production in the specific and non-specific immune response. Am J Reprod Immunol 52: 237-243, 2004.

22. White DL, Tavakoli-Tabasi S, Kuzniarek J, Pascua R, Ramsey DJ and EI-Serag HB: Higher serum testosterone is associated with increased risk of advanced hepatitis C-related liver disease in males. Hepatology 55: 759-768, 2012.

23. Langer C, Gansz B, Goepfert C, Engel T, Uehara Y, von Dehn G, Jansen $\mathrm{H}$, Assmann $\mathrm{G}$ and von Eckardstein A: Testosterone up-regulates scavenger receptor BI and stimulates cholesterol efflux from macrophages. Biochem Biophys Res Commun 296: 1051-1057, 2002.

24. Pennel LM, Galligan CL and Fish EN: Sex affects immunity. J Autoimmun 38: J282-J291, 2012.

25. Klein SL, Jedlicka A and Pekosz A: The Xs and Y of immune responses to viral vaccines. Lancet Infect Dis 10: 338-349, 2010.

26. Bouman A, Heineman MJ and Faas MM: Sex hormones and the immune response in humans. Hum Reprod Update 11: 411-423, 2005.

27. Ackerman LS: Sex hormones and the genesis of autoimmunity. Arch Dermato 142: 371-376, 2006.

28. Gleicher $\mathrm{N}$ and Barad DH: Gender as risk factor for autoimmune diseases. J Autoimmun 28: 1-6, 2007.

29. Rubtsov AV, Rubtsova K, Kappler JW and Marrack P: Genetic and hormonal factors in female-biased autoimmunity. Autoimmun Rev 9: 494-498, 2010. 